\title{
Histological Alterations in Some Organs of African Catfish (Clarias gariepinus) Exposed to Sub-lethal Concentrations of Glyphosate [N- (phosphonomethyl) glycine]
}

\author{
ADEDAMOLA OLADAPO AKINBADEWA ${ }^{1}$, HENRY ADEFISAYO ADEWOLE ${ }^{2}$, \\ STEPHEN A. ADEYENI ${ }^{2} \&$ VICTOR FOLORUNSO OLALEYE ${ }^{2}$
}

\author{
${ }^{1}$ Institute of Ecology and Environmental Studies, Obafemi Awolowo University, Ile-Ife, Nigeria; \\ ${ }^{2}$ Department of Zoology, Obafemi Awolowo University, Ile-Ife, Nigeria \\ Corresponding author: henryadewole@oauife.edu.ng \\ Received: 17 August $2021 \quad$ Accepted: 30 November $2021 \quad$ Published: 31 December 2021
}

\begin{abstract}
This study used a static bioassay to investigate the histological effects of glyphosate on the gill, liver and muscle of African catfish (Clarias gariepinus) fingerlings. This was done with a view of further characterising the effect of glyphosate on $C$. gariepinus fingerlings and other aquatic life forms. Six-week old $C$. gariepinus fingerlings with an average weight of $10.02 \pm 0.2 \mathrm{~g}$ were stocked into three exposure sets (control, $2.75 \mathrm{ppm}$ (25\% of the 96 $\mathrm{h}$ LC50 value) and $5.50 \mathrm{ppm}$ (50\% of the $96 \mathrm{~h} \mathrm{LC50} \mathrm{value))} \mathrm{in} \mathrm{triplicate} \mathrm{at} 30$ fish per tank for 70 days. The $96 \mathrm{~h}$ LC50 value was $11.00 \mathrm{mg} / \mathrm{L}$. Histological examination of the $C$. gariepinus exposed to various sublethal concentrations of glyphosate showed that major histological changes in their organs were concentration dependent such as gill arch vacuolation, excessive mucosal secretions, lifting of epithelial, and epithelium thickening, hyperplasia and telangiectasis in the gills, discolouration, change in form and consistent alterations involving hyperplasia, narrowing of the central nerve, necrosis, pkynosis, blood congestion and vacuolation of the liver, mild hyperplasia and inflammatory responses in the muscle of the fish. The severity of histological alteration was more pronounced in fish organs exposed to $5.50 \mathrm{ppm}$ of glyphosate concentration. This study concluded that the toxicant (glyphosate) is highly toxic to C. gariepinus particularly at a concentration of $5.50 \mathrm{ppm}$, therefore its use near farm lands or adjacent water bodies should be discouraged.
\end{abstract}

Keywords: Alterations, Clarias gariepinus, glyphosate, histology, organs

Copyright: This is an open access article distributed under the terms of the CC-BY-NC-SA(Creative Commons Attribution-NonCommercial-ShareAlike 4.0 International License) which permits unrestricted use, distribution, and reproduction in any medium, for non-commercial purposes, provided the original work of the author(s) is properly cited.

\section{INTRODUCTION}

The increasing intensification of agriculture practices with the use of agrochemical products, coupled with accidental spillage, careless handling and surface runoffs from point of application into adjacent waterbodies has led to increasingly contamination of waterbodies worldwide (Cavas and Konen, 2007; RamirezDuarte et al., 2008; Sabae et al., 2014; Thanomsit et al., 2016; Bawa et al., 2017; Samanta et al., 2018).

Glyphosate, N-(phosphonomethyl) glycine commonly called Roundup ${ }^{\circledR}$ became the most widely used herbicide due to its efficacy, cost effectiveness and non-persistence in the environment (Samanta et al., 2018). Glyphosate which has more than 24 days of half-life in vegetation, has been reported to have a half-life ranging between 9 and 91 days in aquatic environment (Giesy et al., 2000). Although, glyphosate is readily degradable in soil and water by microbes (Rueppel et al., 1977; Samanta et al., 2018) but because of its strong adsorptive nature, glyphosate has tendency of contaminating surface water rather than moving to the groundwater (Reuter, 2011).

The toxicity of glyphosate based herbicide in aquatic environment has been documented on aquatic organisms with lasting effects (Tomlin, 2006; Hued et al., 2012; Shitmae et al., 2013). Among the non-target aquatic organisms, fish has been the most reported organism that is highly sensitive to toxicity of various aquatic pollutants especially herbicides during their early life stages (Jiraungkorskul et al., 2003; Adedeji et al., 2008; Ladipo et al., 2011; Ayanda and Egbamuno, 2012; Bawa et al., 2017). However, other studies had shown the effects of glyphosate formulations on fish survival, growth 
and reproduction of fish in the laboratory (Olurin et al., 2006; Ayoola, 2008b; Okayi et al., 2010; Ayanda and Egbamuno, 2012). According to WHO, toxicity of glyphosate to organism varies depending on test organism and test condition.

Due to the toxicity nature of these chemicals, there is a need to understand in depth the damage this chemical can cause at cellular and subcellular level. Therefore, histological damage of the gills, liver and muscle are highly considered sensitive for detecting such potential adverse effects of pollutant damage due to over time bioaccumulation, because of direct exposure, respiration, biotransformation and xenobiotic metabolism respectively (Gernhofer et al., 2001; Mohamed, 2009; Bawa et al., 2017).

African catfish (Clarias gariepinus) was considered as test fish for toxicity study because of their hardness, fast growth rate, ability to adapt in extreme environmental conditions and good fish of high economic value in Africa (Adewumi and Olaleye, 2005). Also, being a bottom dweller where the name "mudfish" was derived, they can accumulate the pollutant chemicals in the aquatic environment overtime. Therefore, this study aimed to determining the sub-lethal toxicity of glyphosate, N(phosphonomethyl) glycine and its effect on the histology of muscle, gills and liver of African catfish ( $C$. gariepinus) under a laboratory environment.

\section{MATERIALS AND METHODS}

\section{Range Finding and Acute Toxicity Test}

The concentrations of the glyphosate used for the range finding test followed the methods described by Reish and Oshida (1986) and (Obuotor, 2004). From $11.1 \mathrm{ml}$ of Round-up ${ }^{\circledR}$, $4 \mathrm{~g} / \mathrm{L}$ of glyphosate was prepared with proper dilution to obtain five different logarithmic concentrations $(4,0.4,0.04,0.004$, and 0.0004 $\mathrm{g} / \mathrm{L}$ ) of glyphosate in a well labelled tank A - E respectively. Control tank, which was without glyphosate, was labelled as F. The test fish were exposed into the different glyphosate concentrations at 10 fingerlings per treatment in triplicate. Fish mortality was observed after $1 \mathrm{~h}$, $3,6,12,48,72$ and $96 \mathrm{~h}$ of exposure (Reich and Oshida, 1986). Toxicity range value was then estimated from the probit analysis and
Spearman-Karber method of estimating mortality results (Carter et al., 2000).

\section{Acute Toxicity Testing}

Eight graded concentrations $(1.00,4.00,8.00$, $12.00,16.00,20.00,24.00$ and $400.00 \mathrm{ppm})$ of commercial glyphosate formulation (Roundup ${ }^{\circledR}$ ) which was used for $96 \mathrm{~h}$ acute toxicity bioassay in a static exposure system (Obuotor, 2004) were prepared from the result obtained from the range finding tests. Ten randomly selected fingerlings were exposed to each test concentration in triplicates. Mortality was monitored and recorded in each of the exposure tank after $1 \mathrm{~h}$, $3,6,12,24,48,72$ and $96 \mathrm{~h}$. Data collected were analysed using Trimmed Spearman Karber method to determine LC50 value at $96 \mathrm{~h}$.

\section{Chronic Toxicity Test}

Six weeks old African catfish (C. gariepinus) fingerlings with an average weight of $10.02 \pm$ $0.2 \mathrm{~g}$ were obtained from Prime Aquaculture Ltd., Ikorodu, Lagos. The fishes were brought to the Fish Culture Laboratory, Department of Zoology, Obafemi Awolowo University, Ile-Ife, acclimatized for 14 days in an aerated in a glass tank of $150 \mathrm{~L}$. The stocked fingerlings were fed with $2 \mathrm{~mm}$ Coppen's ${ }^{\circledR}$ feed (45\% crude protein) at $4 \%$ their body weight twice a day. After acclimatization, the fish fingerlings randomly selected were carefully introduced into three exposure sets (control, $2.75 \mathrm{ppm}$ (25\% of the 96 h LC50 value) and $5.50 \mathrm{ppm}(50 \%$ of the $96 \mathrm{~h}$ LC50 value)) in triplicate at 30 fish per tank of 40 litres capacity for 70 days. During these periods, the experimental test fingerlings were fed with Coppen's ${ }^{\circledR}$ feed at $4 \%$ body weight. The test solution in each tank was renewed every $72 \mathrm{~h}$ with freshly prepared solutions. During the experiment, the water $\mathrm{pH}$, temperature and dissolved oxygen (D.O.) measured in situ using a portable $\mathrm{pH}$ meter (Model with resolution 0.01 $\mathrm{pH}$ and accuracy of $\pm 0.05 \mathrm{pH}$ ), mercury in glass thermometer and Milkawauke D.O. meter respectively had average values of $25.7 \pm 0.1^{\circ} \mathrm{C}$, $6.79 \pm 0.06$ and $6.22 \pm 0.17 \mathrm{mg} / \mathrm{L}$ also respectively.

\section{Sample Collection}

At the end of experiment after 70 days, five fish each were collected from the treatments. The collected fish were euthanized with $150 \mathrm{mg} / \mathrm{l}$ 
tricane methanesulphonate (MSS-22, sigma) then the muscle, gill and liver of the fish were dissected out, and the collected tissues were fixed in $10 \%$ formalin.

\section{Histological Examinations}

Persevered gills, muscles and liver samples (preserved in 10\% formalin for about $24 \mathrm{~h}$ at 4 ${ }^{\circ} \mathrm{C}$ ) which were dehydrated in sequential order of alcohol 70, 80, 90 and $100 \%$ respectively for 30 minutes were then cleared in xylene, infiltrated with paraffin at $56{ }^{\circ} \mathrm{C}$, and embedded in paraffin wax. Each of the selected tissues were then sectioned at 6-7 $\mu \mathrm{m}$ by means of a rotatory microtome (Model $157 \mathrm{~B}$ and $\mathrm{H}$ ), dehydrated and stained with heamatoxylin and counterstained with eosin. The sections were then examined under a microscope (model 4551 cutting Acces) which has photographic attachment used for photomicrograph. The slides photomicrographs were then used to describe and compare the appearance, histological structure, physiological condition, and arrangement of the tissues from in the exposed tanks and the control according to Luna (1968); Olurin et al. (2006) and (Ogundiran et al., 2009).

\section{Statistical Analysis}

Toxicity range value was estimated from the Probit analysis and Spearman - Karber method of estimating mortality results (Carter et al., 2012).

\section{RESULTS}

\section{Toxicity Indices}

The lethal concentrations were calculated using both the probit method and the SpearmanKarber method (Table 1) giving an ppm and 20.00 ppm for the Probit and Spearman-Karber method respectively. The LC90 of the acute toxicity test was $58.00 \mathrm{ppm}$ while the $95 \%$ confidence lower and upper limits were 30.00 $\mathrm{ppm}$ and $340.00 \mathrm{ppm}$ respectively. The No Observable Effect Concentration was 2.00 ppm with $95 \%$ lower and upper confidence limits of $0.00 \mathrm{ppm}$ and LC50 values of $11.00 \mathrm{ppm}$ and $10.00 \mathrm{ppm}$, respectively with a corresponding 95\% lower confidence limit of $7.00 \mathrm{ppm}$ and $10.00 \mathrm{ppm}$. The $95 \%$ upper confidence limit was recorded as $17.004 .00 \mathrm{ppm} \mu \mathrm{g} / \mathrm{l}$ respectively. The inhibition concentration (IC25) was seen to be $1.00 \mathrm{ppm}$. The $95 \%$ lower confidence limit was $0.00 \mathrm{ppm}$ while the $95 \%$ upper confidence limit was calculated as $3.00 \mathrm{ppm}$. The observed behavior of the exposed fish at different concentration include: imbalance and incoherent coordination, erratic swimming, gulping of air and restlessness.

Table 1. Toxicity indices for acute toxicity test

\begin{tabular}{cccc}
\hline Index & $\begin{array}{c}\text { Concentration } \\
(\mathrm{ppm})\end{array}$ & $\begin{array}{c}\text { LCL } \\
\end{array}$ & $\begin{array}{c}\text { UCL } \\
(\mathrm{ppm})\end{array}$ \\
& & $(\mathrm{ppm})$ \\
\hline LC50 & 11.00 & 7.00 & 17.00 \\
LC90 & 58.00 & 30.00 & 340.00 \\
NOEC & 2.00 & 0.00 & 4.00 \\
IC25 & 1.00 & 0.00 & 3.00 \\
\hline
\end{tabular}

LC50- Lethal concentration that killed 50\% of the test fish

LC90- Lethal concentration that killed $90 \%$ of the test fish

NOEC- No observable effect concentration IC25- Inhibition concentration with $25 \%$ reduction in growth

LCL- Lower confidence limit

UCL- Upper confidence limit 


\section{Histological Changes in the Gills}

The control fish gills appeared normal in form and consistency during gross examination with a bright red colour. Slide photomicrograph examinations revealed normal structure of the gill arch showing blood spaces in the lamellae. Primary lamellae appeared fine and distinct with no signs of epithelial lifting, no signs of inflammation, cellular hypertrophy and hyperplasia. The base of primary lamellae showed cells of similar size which were sparsely distributed evenly. Normal blood space congestion was observed in one of the lamellae as show in Figure 1.

There were observable changes in the gill tissues of fish following treatments with glyphosate during the experiment showing histological alterations. Gross examination of gill tissues of fish in Treatment A (2.75 ppm) showed a fairly firm consistency and bright reddish colour comparable to that of the control (Figure 2). Histological examination showed gill arch vacuolation, thickening of the primary lamella, which became blunt and not finely distinct with signs of mucosal secretions, slight epithelial lifting were seen hyperplasia (Figure 2 (b)). Severe diapedesis and blood congestion were also visible in the lamella (Figure 2 (a), (b)). Lamella base were observed to have a thickened denser cellular network compared to the control group suggesting increase in cells and mucous productions with an area of inflammation (Figure 2 (c), (d)).

Gill tissues in Treatment B (5.50 ppm) showed a severe alteration in the gill histology. Gross examination of the tissue showed colour changes from light red to brown colour. Microscopic examination of the tissue revealed severe damage of the gills due to glyphosate exposure. Severe cellular erosion was seen in the gill tissues, lamella rupture was conspicuously obvious, epithelial erosion and cellular hypertrophy were also observed in lamella base (Figure 3 (a), (b), (c), (d)).

\section{Histological Changes in the Liver}

The liver tissues of fish in the control group showed no conspicuous alteration in the cells as shown in Figure 4. The cells appear normal with a large spherical central vein. Hepactic sinusoides appear firm and free of fluid congestions with high vascularisation and haemorrhage around the spheres of the central nerve. Hepatocytes appear firm with a darkly stained nucleus and nucleolus. Glycogen vacoules were visible as spherical bright spaces. Amongst the control group liver tissues, there were no signs of necrosis, cellular degeneration, pyknosis, hypertrophy, hyperplasis and necrosis. However, the sinoides were highly vascularised with blood concentrated around the central vein. Liver tissues of fish exposed to glyphosate showed alterations in tissue form and structure. Gross examination revealed brownish-yellowish colourations of the liver lobes. Histological examination of fish in Treatment A (2.75 ppm) revealed higher vascularisation of the sinusoids supplying the central bile duct with evidence of hypatocytes hyperplasia and telangiectasis (Plate 5 (a), (b)). Mild pyknosis were observed suggesting cell deaths and degeneration although this was minimal in the Treatment B $(5.50 \mathrm{ppm})$. Blood congestion and vasodilation was seen in the liver tissues along the sinusoides which is as a result of increased liver function. The form and consistency of the bile duct was also observed to be distorted and narrowing (Figure 6 (a), (b)).

\section{Histological Changes in the Muscles}

The fish muscles showed no serious distortion. Both white muscle and red muscle of the fish were observed to be show normal histological structures with a revealing striated muscle cells (Figure 7a). The cells possessed a darkly stained nucleus. No severe histological distortions were observed in the tissues of all treatments unless an area of suspected inflammation.

Treatment A (2.75 ppm) had its muscle tissues just like the control group with only signs of mild cellular hyperplasia, nevertheless, the structure appeared just like the Control (Figure $7 b)$. However, treatment with the highest glyphosate concentration $(5.50 \mathrm{ppm})$ showed signs of mild inflammation and cellular distortions with likely hyperplasia (Figure 7 (c)). 


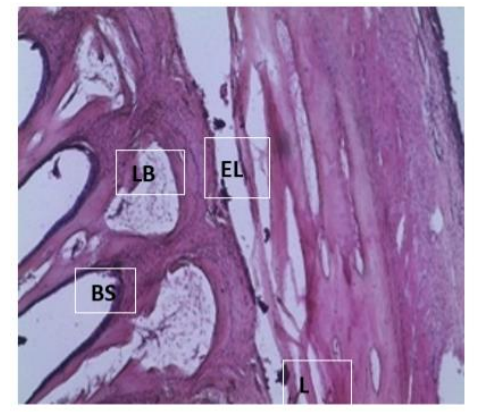

(a)

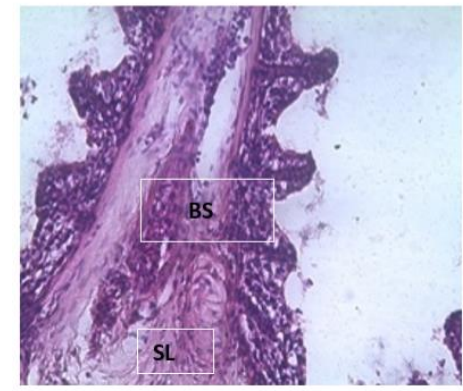

(c)

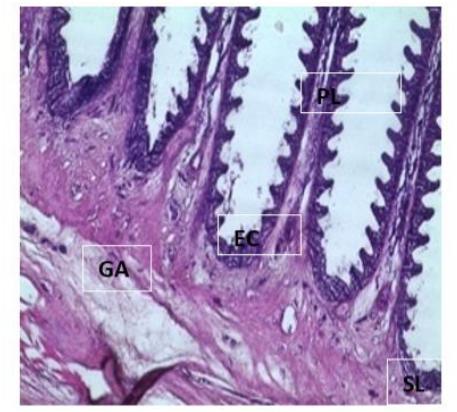

(b)

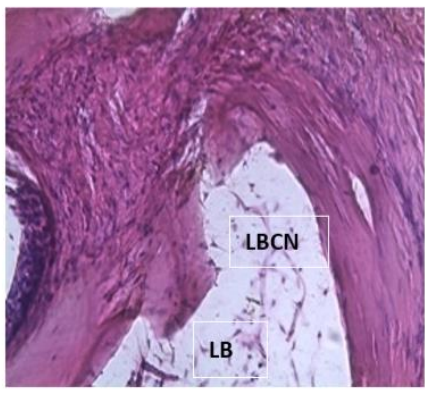

(d)

Figure 1. Histological photomicrographs of the gill tissues of $C$. gariepinus under control condition showing normal (a) LB-lamella base, EL-epithelial lifting, L-lamella, BS-blood spaces, (X100) (b) PL-primary lamella, GA-gill arch, EC-erythrocyte cell, SL-secondary lamella, (X100) (c) BS-blood spaces, SL-secondary lamella, (X400) and (d) LBCN-lamella base cell network, LB-lamella base, (X400)

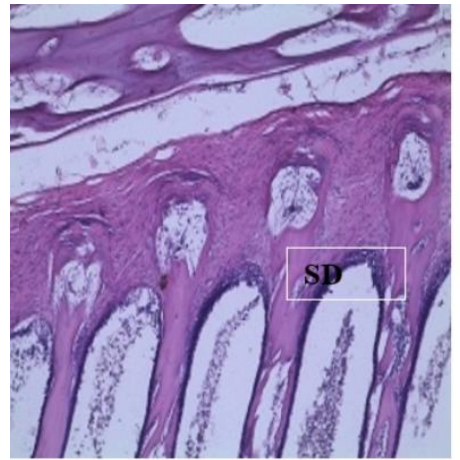

(a)

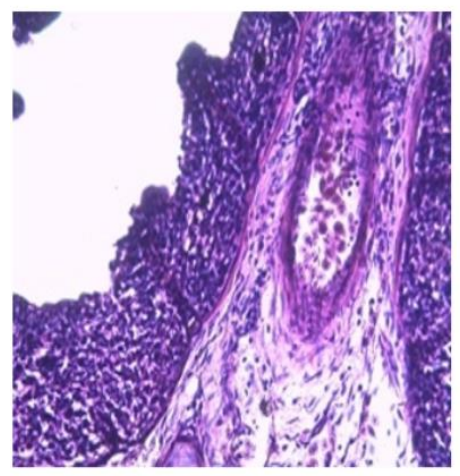

(c)

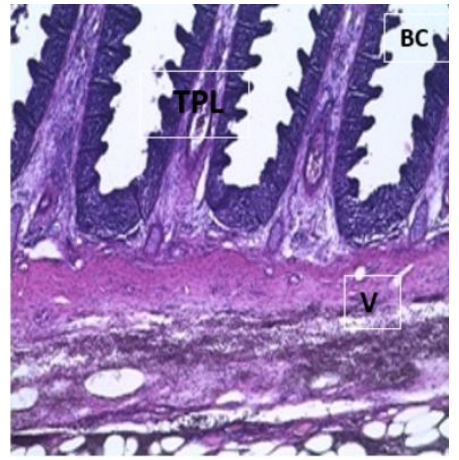

(b)

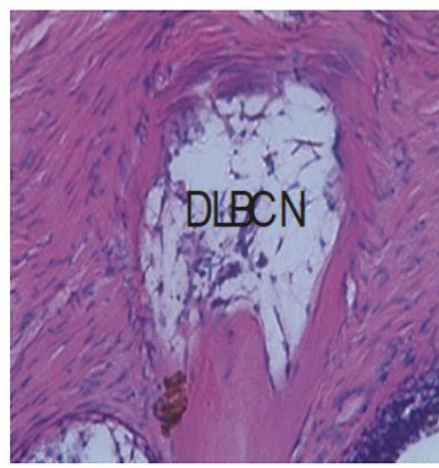

(d)

Figure 2. Histological photomicrographs of the gill tissues of $C$. gariepinus exposed to $2.75 \mathrm{ppm}$ concentration of glyphosate showing (a) SD- severe diapedesis, (X100) (b) BC- blood congestion, V-vacoulation, (X100) (c) TPL-thickened primary lamella, BC-blood congestion, CHP-cellular hyperplasia, (X400) and (d) DLBCN-dense lamella base cell network (X400) 


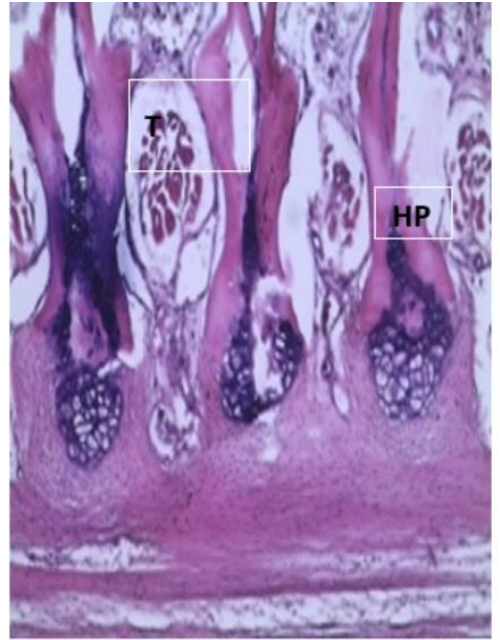

(a)

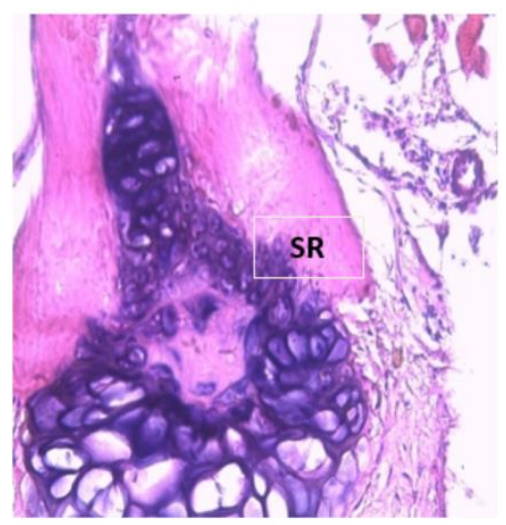

(c)

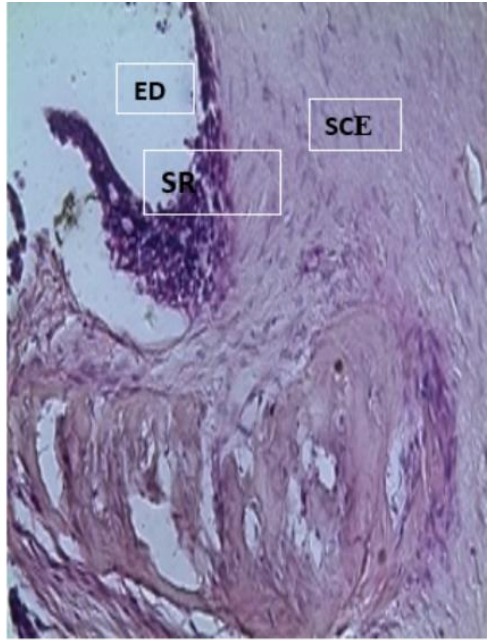

(b)

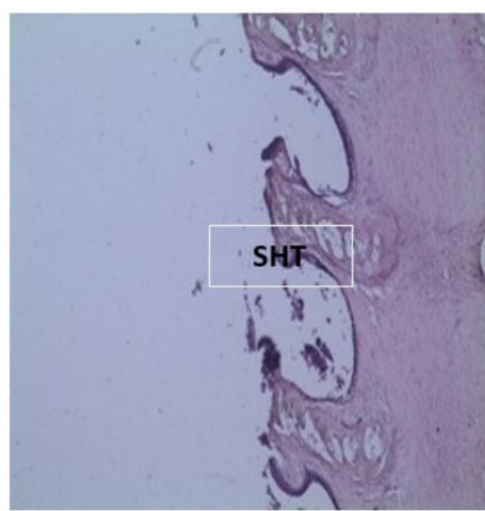

(d)

Figure 3. Histological photomicrographs of the gill tissues of $C$. gariepinus exposed to 5.50 ppm concentration of glyphosate showing (a) T-telangiectasis, (X100) (b) ED-epithelial degeneration, SR-severe rupture, SCEsevere cellular erosion, (X100) (c) SR-severe rupture, (X400) and (d) SHT-severe hypertrophy, (X400)

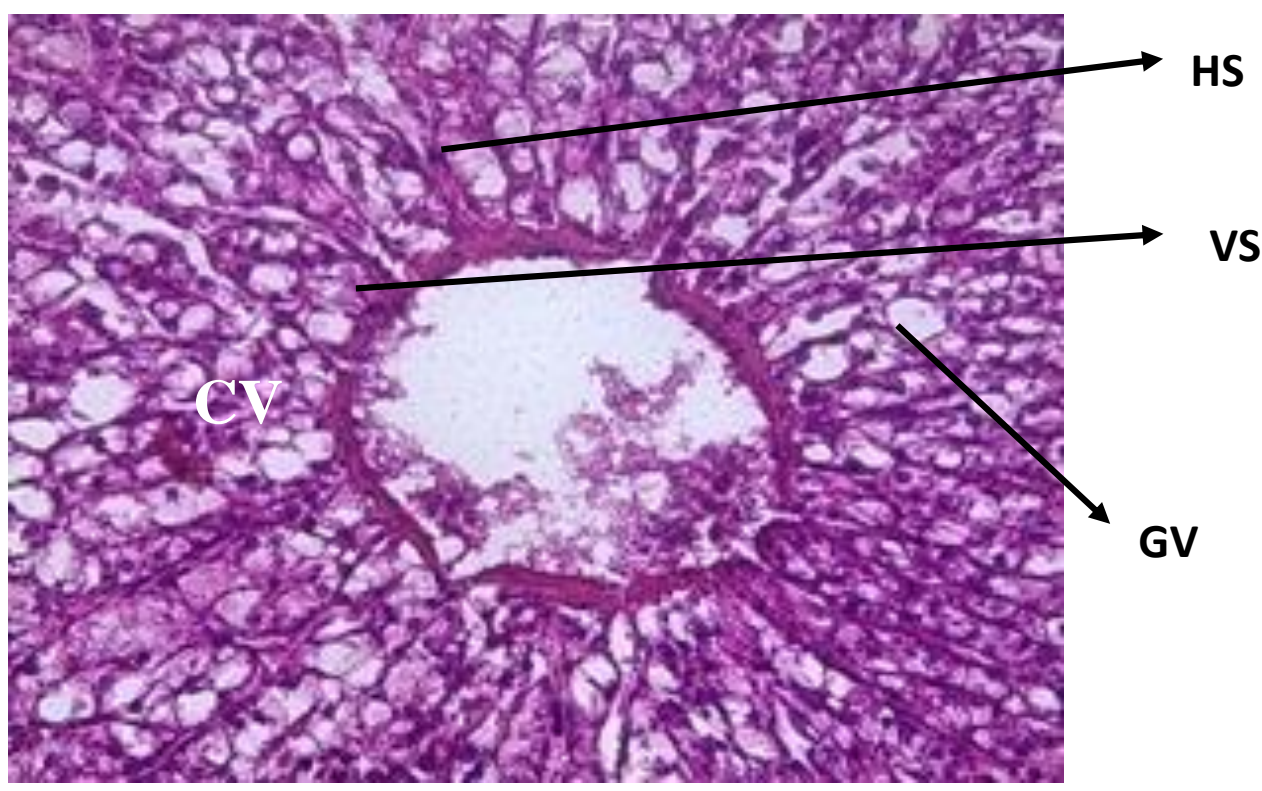

Figure 4. Histological photomicrographs of the liver section of $C$. gariepinus under control treatment showing HS-hepactic sinusoides; VS-vascularised sinusoides; CV-central vein; GV-glycogen vacuole (X400) 


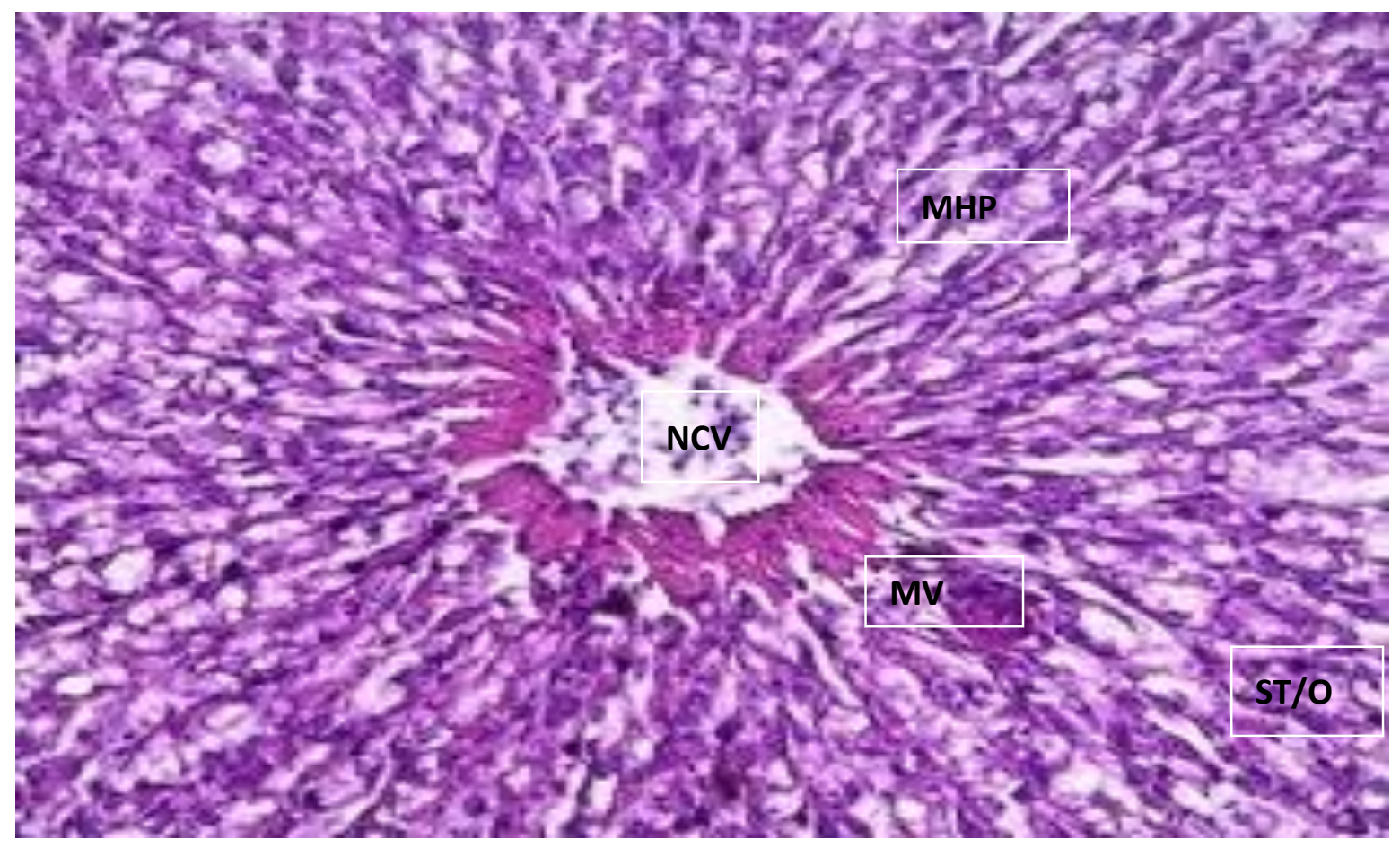

(a)

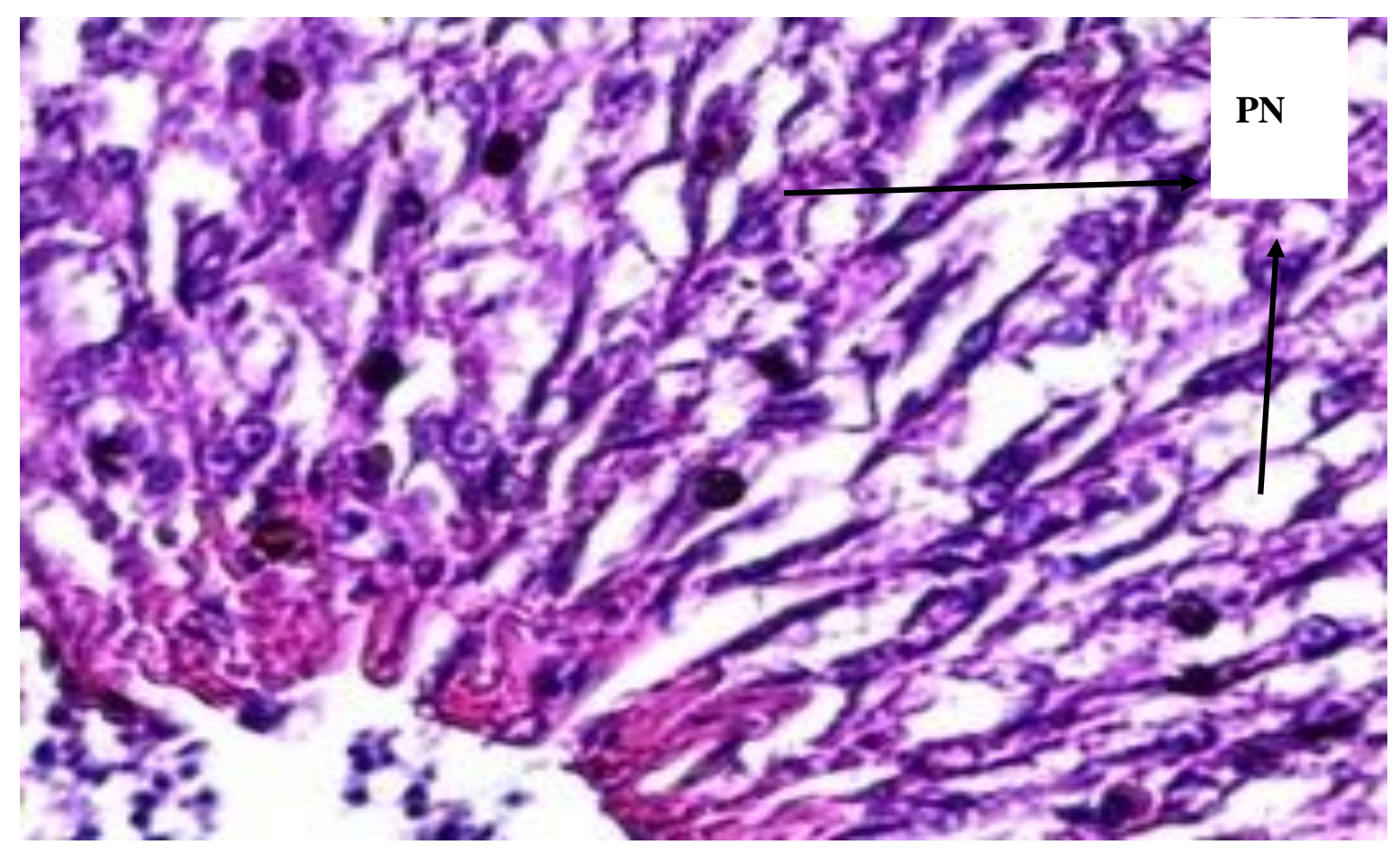

(b)

Figure 5. Histological photomicrographs of the liver section of $C$. gariepinus exposed to 2.75 ppm concentration of glyphosate showing (a) MHP-mild hyperplasia; NCV-narrowing of the central nerve; ST/O-sinusoidal telangiectasis/oedema, (X400) and (b) PN-pyknotic nuclei, MV-mild vacuolisation (X1000) 


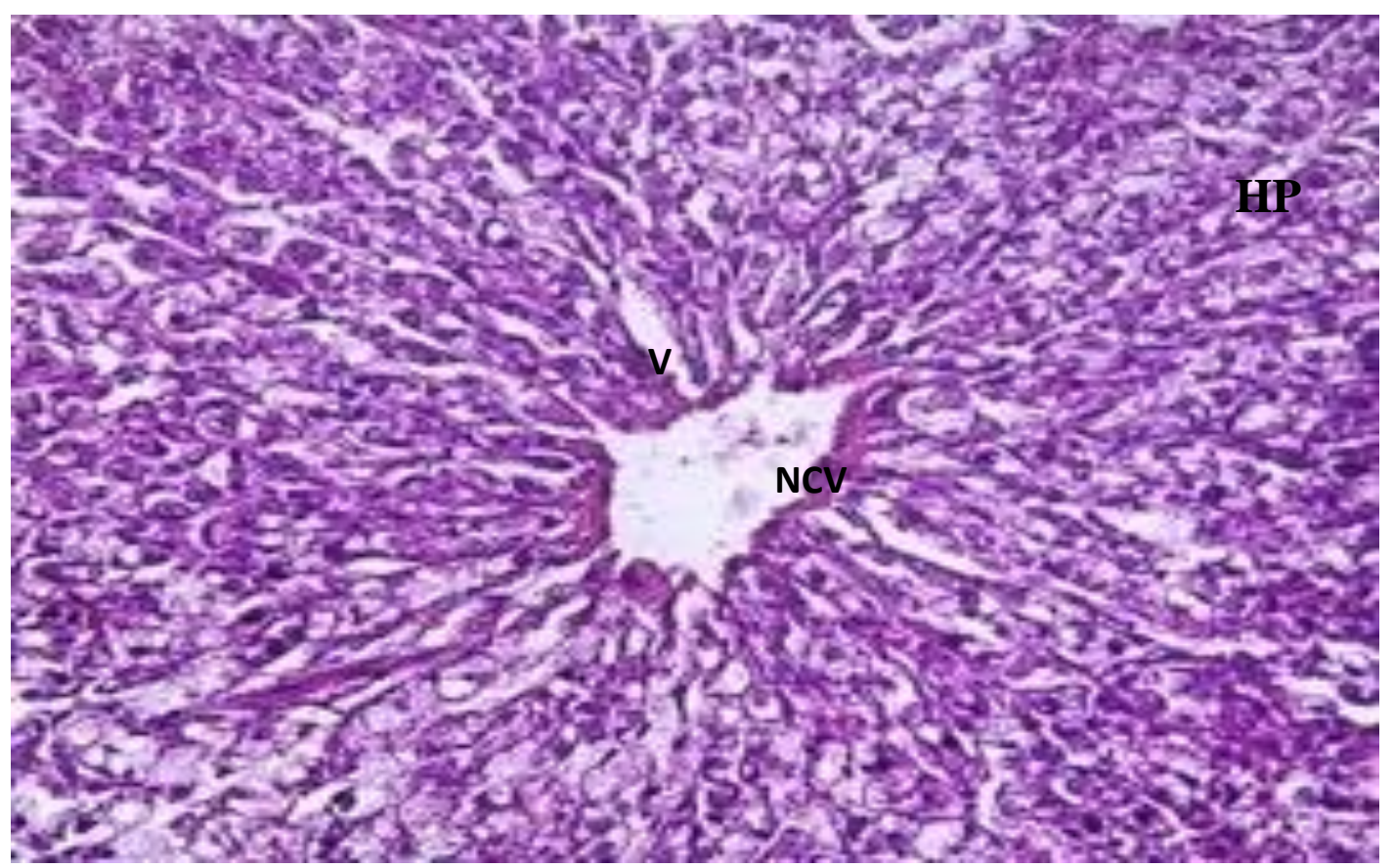

(a)

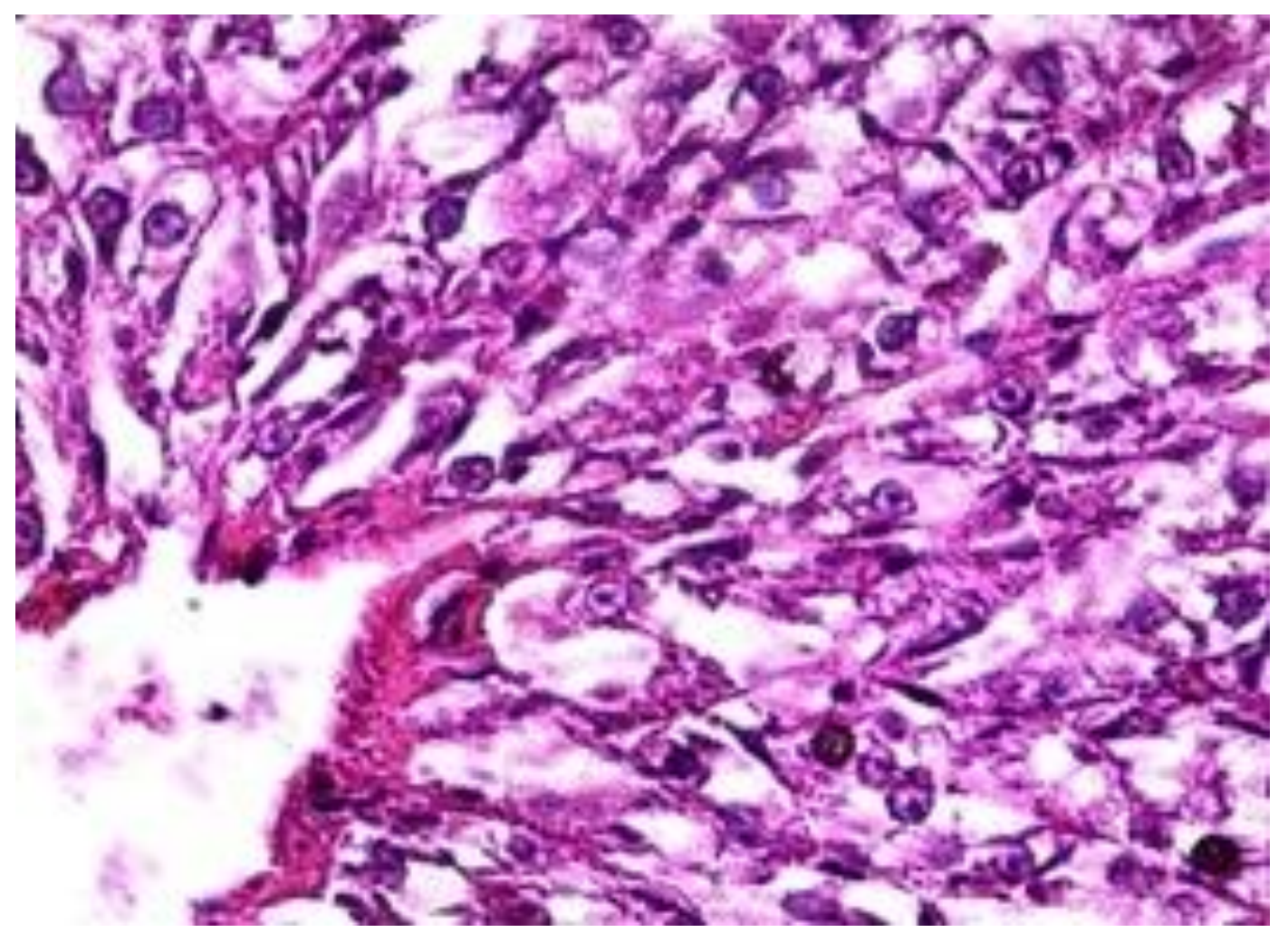

(b)

Figure 6. Histological photomicrographs of the liver section of $C$. gariepinus exposed to $5.50 \mathrm{ppm}$ concentration of glyphosate showing (a) HP-hyperplasia; NCV-narrowing of central vein, V-vacuolation, (X400) and (b) VDvasodilatation; N-necrosis; BC-blood congestion (X1000) 


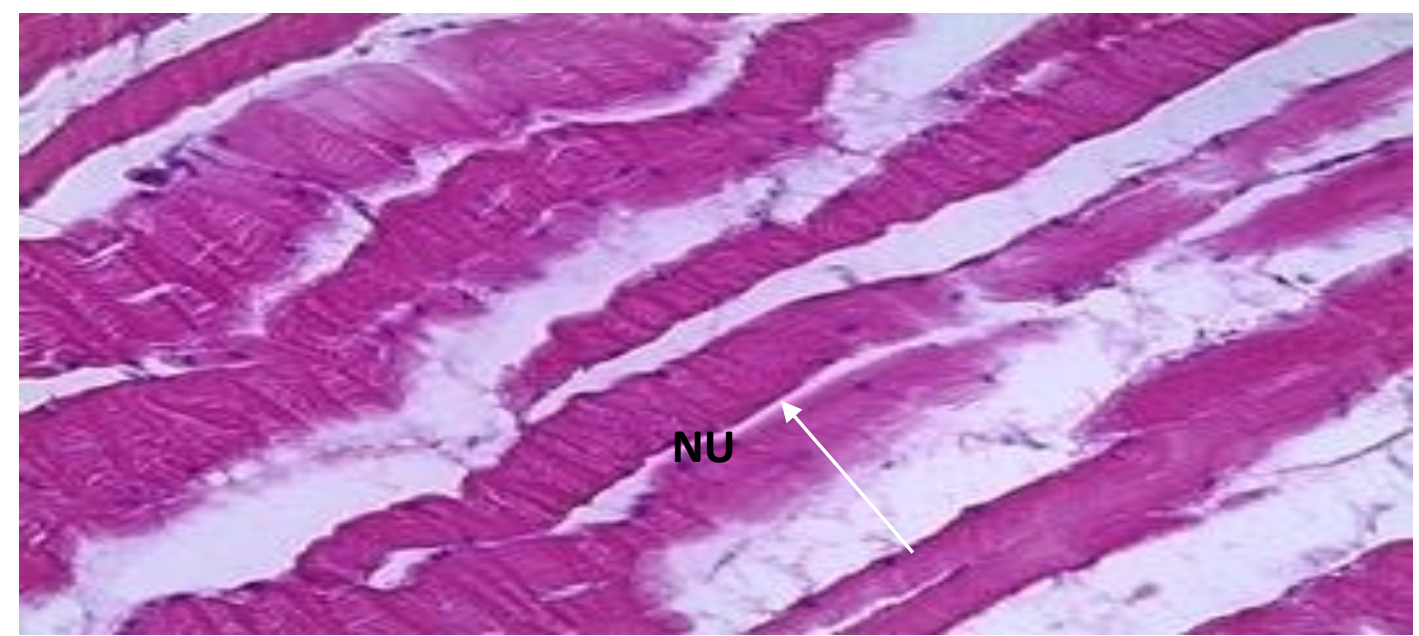

(a)

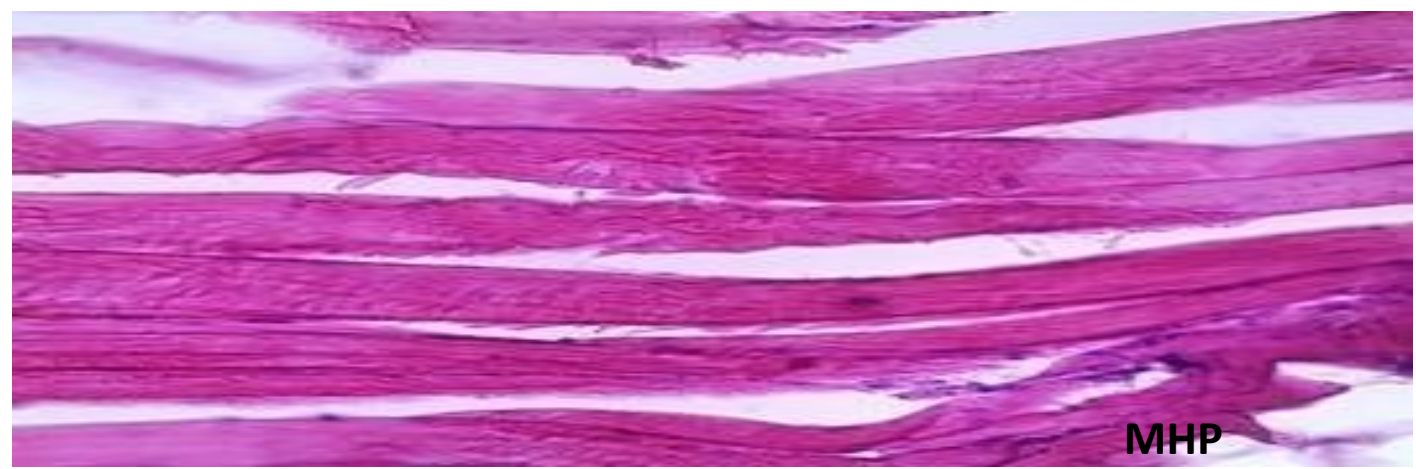

(b)

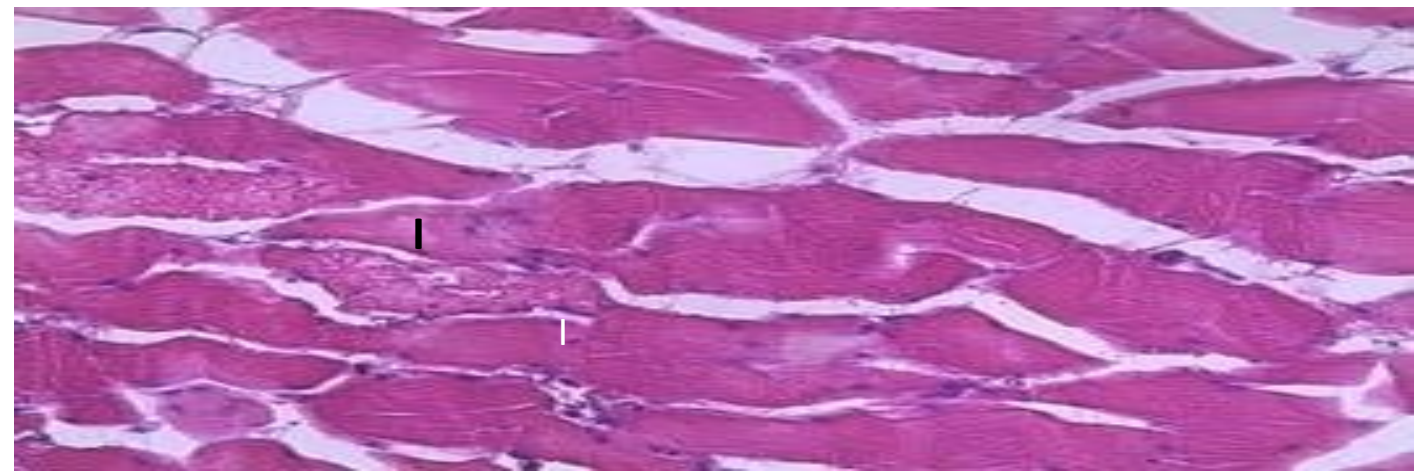

(c)

Figure 7. Histological photomicrographs of the muscle section of $C$. gariepinus under (a) control treatment, Treatment A (2.75 ppm) showing normal muscle cell structure revealing the striated muscle cells with nucleus (X400) (b) Treatment A (2.75v ppm) showing similar muscle cells with fish in the control with signs of mild cellular hyperplasia (X400) and (c) Treatment B (5.5 ppm) showing signs of mild inflammation and cellular distortions (X400)

\section{DISCUSSION}

The Probit and Spearman-Karber LC50 values were $11.00 \mathrm{ppm}$ and $10 \mathrm{ppm}$ respectively. This value was above the $96 \mathrm{~h}$ LC50 value of glyphosate herbicide of $0.04 \mathrm{ppm}$ reported by Ayoola (2008b) and above the $1.8 \mathrm{ppm}$ reported by Okayi (2010) in a toxicity test of glyphosate to juvenile $C$. gariepinus and with a corresponding 95\% lower confidence limit of $7.00 \mathrm{ppm}$ and $10.00 \mathrm{ppm}$. The 95\% upper confidence limit was recorded as $17.00 \mathrm{ppm}$ and 20.00 ppm for the Probit and Spearman-Karber method respectively.

The result of LC50 value of the acute toxicity test in this study revealed that $C$. gariepinus showed a higher sensitivity to glyphosate when compared to the Tilapia fish, 
Oreochromis niloticus which recorded an LC50 value of $1.05 \mathrm{mg} / \mathrm{l}$ in a $96 \mathrm{~h}$ acute toxicity test (Ayoola, 2008a) but was however lower in comparison with Cachama blanca (Piaractus brachypomus) which can tolerate glyphosate more at LC50 value of $97.47 \mathrm{mg} / \mathrm{L}$ in acute toxicity test. This observation was in consonance with earlier reports on the increasing toxicity with increased concentrations of xenobiotics (Ayoola, 2008b; Ogundiran et al., 2009; Hadi and Alwan, 2012; Selvanathan, 2013). Bioaccumulation rate, organism responses, and reaction of different compound of the pesticide composition determines the toxicity level of any pesticide (Neibor and Richardson, 1980). Folmar et al. (1979) also reported acute toxicity of glyphosate in fish as a consequence of the POEMA surfactant.

Normal fish behavior observed in the control group with incoherent coordination and balance, erratic swimming, gasping for air and restlessness observed in the exposed treatments was also reported by Bawa et al. (2017) and Samanta et al. (2018) on histological alteration of Cyprinus carpio and Oreochromis niloticus, respectively exposed to glyphosate. This behavior could be attributed to respiratory impairment, nerve and or brain damage, probably because toxicant glyphosate that is present water affects the gills which are the first point of contact.

The histological changes in fish are important aspect in substance toxicology to understand the extent to which changes in the structural organisation are occurring in the organs due to environmental pollution (Myers et al., 1998; Ramirez-Duarte et al., 2008; Samanta et al., 2018). Various researchers had studied and reported environmental pollution and its effects on aquatic animals of economic importance. Study on effect of glyphosate on fish histology is gaining popularity due to its significance in toxicology (Olurin et al., 2006; Ayoola, 2008b; Ayoola and Egbamuno, 2012). Selvanathan et al. (2013) studied histopathology changes in C. batrachus exposed to mercury and cadmium while Hadi and Alwan (2012) assessed the changes in the histology of Tilapia zillii's gills, liver and kidney. Histological changes in the kidney, liver, and gill of carps exposed to sublethal toxicity of glyphosate concentration was also researched by Neskovic et al. (1996).
Similarly, Ayoola (2008b) carried out a study of glyphosate on histology of $C$. gariepinus and $T$. zillii in a short toxicity test. In this study, the histological changes in the muscles, gills, and liver of $C$. gariepinus juveniles were examined after a 70 days of exposure to sublethal concentrations of glyphosate.

Fish gills are the principal organ of gaseous exchange between the fish and the water environment and a direct opening between the internal environment and the external environment (Sullivan and Somero, 1993). Histological alterations in several fish gills as a result of direct and indirect exposure to pesticides and various contaminants have been documented by many authors (Mallat, 1985; Richmonds and Dutta, 1989; Ayoola, 2008a; Ayoola, 2008b; Ogundiran et al., 2009; Hadi and Alwan, 2012, Selvanathan et al., 2013). Gills which have interface area that is very large between internal and external environment of fish, and playing important role in exchange of gases, ion osmo-regulation, acid-base balance and excretion of nitrogenous wastes, are the first contact organ of several pollutants that are partially sensitive to adverse environmental conditions (Heath, 1987; Ogundiran et al., 2009). Primarily, pesticides and other contaminants enters the fish through the gills while the liver function mainly in detoxification (Dutta et al., 1994).

In this study, major histological changes were observed in the gills of fish exposed to sublethal glyphosate concentrations. These changes include gill arch vacoulation, excessive mucosal secretions, epithelial lifting, and thickening of the epithelium, hyperplasia, diapedesis, blood congestion, inflammation, lamellar ruptures, cellular hypertrophy, epithelial erosion and telangiectasis most of which have been documented upon fish exposure to various toxicants in water such as heavy metals, pesticides, and detergents (Nowak, 1992; Ortiz et al., 2003; Ayoola, 2008a; Ayoola, 2008b; Hadi and Alwan, 2012). These histological conditions observed in this study were as a result of the toxicity of the herbicide to the gill tissues and this toxic effect may have resulted into osmoregulatory stress and respiratory inefficiency due to reduced surface area, blood congestion in the gill capillaries, cellular distortion and erosion of cells. The damage in terms of rupture of gill 
epithelium, cellular hypertrophy and inflammation leads to hypoxia and fish inability to respire. Epithelial lifting and erosion and telangiectasis were direct responses to the action of glyphosate. The severity of this condition in the gills of fish exposed to highest glyphosate concentration indicates its concentration dependence.

Liver is an important organ that plays vital roles such as synthesis of several components of blood plasma, release of glucose to the blood, glycogen storage and detoxification (Ortiz et al., 2003). Morphological and histological alterations in liver of fish related to toxic chemical exposures have been extensively studies, showing that these substances cause severe damage to the liver cells (Dutta, 1994; Ortiz et al., 2003; Hadi and Alwan, 2012; Ayoola, 2008b). The evaluation of histological alteration in liver of fish is a highly sensitive and precise way to determining xenobiotic compounds effects in field and experimental studies (Figueiredo-Fernandes et al., 1979). The alterations in the histology of the fish liver in this study were concentration dependent. Degeneration observed in the structure of the exposed fish indicates the excessive activities of the liver as a detoxifying organ trying to get rid of the toxicant from the body of the animal (Monir et al., 2015; Bawa et al., 2017). Congestion of sinusoids, leisons in the liver, lipidic vacuoles, focal necrosis, infiltration of leucocytes and pykonic nuclei are reported pathological effects of various herbicides (Couch, 1975; Neskovic et al., 1996; Jiraungkoorsul et al., 2003; Monir et al., 2015; Bawa et al., 2017). The pykonic nuclei observed in the liver of the fish exposed to $2.75 \mathrm{ppm}$ glyphosate concentration is an indication of undergoing necrosis or apoptosis. This could be due to alterations in the protein metabolism and synthesis due to failures in the transcription process caused by glyphosate (Papadimitou et al., 2000; Jiraungkoorsul et al., 2003; Marc et al., 2005) The observed vasolidation and necrosis in fish exposed to higher glyphosate concentration $(5.50 \mathrm{ppm})$ confirmed the complete stage of pykonic nuclei leading to blood vessel widening resulting from underlining disease which may be due to glyphosate exposure. The observed necrosis of liver cells could also be due to the inability of the fish to grow new cell (Camargo and Martinez, 2007; Deivasigamani, 2015).
Narrowing of the central nerve and vasodilatation in the liver sinusoids could be seen to be as a direct effect of the herbicide to the liver.

The fish muscle tissues in this study showed no apparent histological changes unless for mild hyperplasia and inflammatory responses observed in groups with glyphosate treatment. Inflammation is a common response of animal tissues to toxin as a result of cellular degeneration and haemorrhage (Ladipo et al., 2011). However, these were not conspicuous in the examined tissue sample. The skeletal muscle cells consisting of both the white and brown muscles showed normal striation and nucleation of the tissues with distinct adipose tissues suggesting a minimal effect of glyphosate on the muscles of the fish.

\section{CONCLUSION}

The pronounced harmful histological changes induced by glyphosate on the organs studied reveals that exposure of fish to chemical environmental stressors can lead to tissue distortion and death of the fish. The toxicity of glyphosate on juvenile fish increases with increasing levels of toxins due to accumulation of the toxic substance and its associated effects. This study revealed that glyphosate herbicide is a potent toxin particularly at a concentration of $5.50 \mathrm{ppm}$ to fingerlings of African catfish $(C$. gariepinus) and results in deadly histological changes in vital organs especially in gills and liver.

\section{ACKNOWLEDGEMENTS}

The authors acknowledge the contribution of Mr. Akinkuolie Samuel and Mr. Ayodeji Oluwafisayo for their assistance in the laboratory during this period of this research work. The authors also appreciate the Department of Zoology, Obafemi Awolowo University for making available the needed facilities and equipment.

\section{REFERENCES}

Adedeji O.B., Adedeji A.O., Adeyemo O.K. \& Agbede S.A. (2008). Acute toxicity of diazinon to the African catfish (Clarias gariepinus). African Journal of Biotechnology, 7(5): 651-654. 
Ayanda, O.I. \& Egbamuno, E.A. (2012). Histopathological examination of the liver and gills of Clarias gariepinus treated with glyphosate. Journal of Enviromental Research, 6(3): 228-234.

Ayoola S.O. (2008a). Toxicity of glyphosate herbicide on Nile tilapia (Oreochromis niloticus) juvenile. African Journal of Agricultural Research, 3(12):825-834.

Ayoola, S.O. (2008b). Histopathological effects of glyphosate on juvenile African catfish (Clarias gariepinus). European Journal of Agriculture and Environmental Science, 4(13): 362-367.

Bawa, V., Kondal, J.K., Hundal, S. S., \& Harpinder K. (2017). Biochemical and histological effects of glyphosate on the liver of Cyprinus carpio (Linn.). American Journal of Life Sciences. Environmental Toxicology, 5(3-1): 71-80.

Carter, K., Rao, C., Lopez, A.D. \& Taylor, R. (2012). Mortality and cause-of-death reporting and analysis systems in seven pacific island countries. BMC Journal of Public Health, 12: 436-445.

Camargo, M.M.P. \& Martinez, C.B.R. (2007). Histopathology of gills, kidney and liver of a Neotropical fish caged in an urban stream. Neotropical Ichthyology, 5(3): 327-336.

Cavas, T. \& Konen, S. (2007). Detection of cytogenetic and DNA damage in peripheral erythrocytes of goldfish (Carassius auratus) exposed to glyphosate formulation using the micronucleus test and the comet assay. Mutagenesis, 22: 263-68.

Couch, J. A. (1975). Histological effects of pesticides and related chemicals on the liver of fish. In: Ribelin, W.E. Magaki, G. (eds.). The Pathology of Fishes. The University of Wisconsin Press, Madison, Wisconson, USA 559-575.

Deivasigamani, S. (2015). Effect of herbicides on fish and histological evaluation of common carp (Cyprinus carpio). International Journal of Applied Research, 1 :437-440.

Dutta, M.H., Munshi, D.J. \& Roy K.P. (1994). Malathion induced changes in the lymphatic system of a catfish, Heteropneusles fossilis. Journal of Integrated Comparative Biology, 34(5): 50-53.

Figueiredo-Fernandes, A., Ferreira-Cardoso J.V., Garcia-Santos S., Monteiro S.M., Carrola Folmar, L.C., Sanders, J.O. \& Julin, A.M. (1979). Toxicity of the herbicides glyphosate and several of its formations to fish and aquatic invertebrates. Journal of Environmental Contamination Toxicology, 8: 269-278.

Folmar, L.C., Sanders, H.O. \& Julin A.M. (1979). Toxicity of the herbicide glyphosphate and several of its formulations to fish and aquatic invertebrates. Archives of Environmental Contamination and Toxicology, 8: 269-278.

Gernhöfer, M., Pawert, M., Schramm, M., Müller, E. \& Triebskorn, R. (2001). Ultrastructural biomarkers as tools to characterize the health status of fish in contaminated streams. Journal of Aquatic Ecosystem Stress and Recovery, 8: 241-60.

Giesy, J.P., Dobson S. \& Solomon K.R. (2000). Ecotoxicological risk assessment for roundup herbicide. Review of Environmental Contamination and Toxicology, 167: 35-120.

Hadi, A.A. \& Alwan S.F. (2012). Histopathological changes in gills, liver and kidney of fresh water fish, Tilapia zillii, exposed to aluminium. International Journal of Pharmacy and Life Science, 3(11): 2071-2081.

Heath, A.G. (1987). Water Pollution and Fish Physiology. CRC Press, Florida. Pp. 71 - 73.

Hued, A.C., Oberhofer, S. \& de los Ángeles-Bistoni, M. (2012). Exposure to a commercial glyphosate formulation (Roundup ${ }^{\circledR}$ ) alters normal gill and liver histology and affects male sexual activity of Jenynsia multidentata (Anablepidae, Cyprinodontiformes). Archives of Environmental Contamination and Toxicology, 62: 107-17.

Jiraungkoorskul, W., Upatham, E.S., Kruatrachue, M., Sahaphong, S., Vichasri-Grams, S. \& Pokethitiyook, P. (2003). Biochemical and histopathological effects of glyphosate on Nile tilapia (Oreochromis niloticus). Environmental Toxicology, 18: 260-267.

Ladipo, M.K., Doherty, V.F., \& Oyebadejo, S.A. (2011). Acute toxicity, behavioural changes and histopathological effect of paraquat dichloride on tissues of catfish (Clarias gariepinus). International Journal of Biology, 3(2): 67-74.

Luna, L.G (1968). Manual of Histologic Staining Method of the Armed Forces Institude of Pathology. New York: Mcgraw-Hill. Pp. 73-76.

Mallatt, J. (1985). Fish gill structural changes induced by toxicants and other irritants: a 
statistical review. Canadian Journal of Fish and Aquatic Sciences, 42: 630-648.

Marc, J., Le Breton, M., Cormier, P., Morales, J., Belle, R., \& Mulner-Lorillon, O. (2005). A glyphosate-based pesticide impinges on transcription. Journal of Toxicology and Applied Pharmacology, 203: 1-8.

Mohamed, F.A. (2009) Histopathological studies on Tilapia zillii and Solea vulguris from Lake Qarun, Egypt. World Journal of Fish and Marine Science, 1: 29-39.

Monir, M.S., Doulah, M.A.U., Rahman, M.K., Akhter, J.N. \& Hossain, M.R. (2015). Effect of cypermethrin on the histoarchitecture of gills and liver of freshwater catfish, Pangasianodon hypophthalmus. Asian Journal of Medicine and Biology Research, 1(3): 641-647.

Myers, M.S., Johnson, L.L., Hom, T., Coiler, T.K., Stein, J.E. \& Varanasi, V. (1998). Toxicopathic hepatic lesions in subadult English sole from Puget sound, WA; relationship to other indicators of contaminant exposure. Journal of Marine Environmental Resources, 45: 47-67.

Neibor, E. \& Richardson, D.H. (1980). Replacement of non-descript term heavy metal by a biological and chemically significant classification of metal ions. Environmental Pollution Series, 3(1): 24-45.

Neskovic, N.K., Poleksic, V., Elezovic, I., Karan, V. \& Budimir, M. (1996). Biochemical and histopathological effects of glyphosate on carp (Cyprinus carpio). Bulletin of Environmental Contamination Toxicology, 56: 295-302.

Nowak, B. (1992). Histological changes in gills induced by residues of endosulfan. Journal of Aquatic Toxicology, 23: 63-84.

Ogundiran, M.A., Fawole, O.O., Adewoye, S.O. \& Ayandiran, T.A. (2009). Pathologic lesions in the gills of Clarias gariepinus exposed to sublethal concentrations of soap and detergent effluents. Journal of Cell and Animal Biology, 3 (5): 78-82.

Okayi R.G., Aunue, P.A., Tachia, M.U. \& Oshoke, O.J. (2010). Acute toxicity of glyphosate on Clarias gariepinus fingerlings. Journal of Research in Forestry, Wildlife and Environment, 2(2): 150-154.

Olurin, K.B., Olojo, E.A.A., Mbaka, G., \& Akindele, A.T. (2006). Histopathological responses of the gill and liver tissues of Clarias gariepinus fingerlings to the herbicide glyphosate. African Journal of Biotechnology, 5 (24): 2480-2487.
Ortiz, R.M., Noren, D.P., Ortiz, C.L. \& Talamantes, F. (2003). GTL and gherlin increase with fasting in a naturally adapted species, the northern elephant seal (Mirounga angustirostris). Journal of Endocrinology, 178: 533-539.

Pacheco, M. \& Santos, M.A. (2002). Biotransformation, genotoxic and histopathological effects of environmental contaminants in European eel, Anguilla anguilla L. Eco-toxicology and Environmental Safety, 53: 331-347.

Papadimitriou, J.C., Drachenberg, C.B., Brenner, D.S., Newkirk, C., Trump, B.F. \& Silverberg, S.G. (2000). "Thanatosomes": A unifying morpho-genetic concept for tumor hyaline globules related to apoptosis. Human Pathology, 31: 1455-1465.

Ramírez-Duarte, W.F., Rondón-Barragán, I.S. \& Eslava-Mocha, P.R. (2008). Acute toxicity and histopathological alterations of Roundup ${ }^{\circledR}$ herbicide on "Cachama blanca" (Piaractus brachypomus). Pesquisa Veterinaria Brasileira, 28(11): 547-554.

Reish, D.L. \& Oshida, O.S. (1986). Manual of methods in aquatic environmental research. Part 10. Short-term bioassays. -FAO Fisheries Technical Paper 247, Rome, Pp. 62.

Richmonds, C. \& Dulta, H.M. (1989). Histopatholigical changes induced by malathion in the gills of blue gill. Lepomis macrochinis. Bulletin Environmental Contamination Toxicology, 43: 123-130.

Rueppel, M.L., Brightwell, B.B., Schaefer, J. \& Marvel, J.T. (1977). Metabolism and degradation of glyphosate in soil and water. Journal of Agricultural and Food Chemistry, 25(3): 517-528.

Sabae, S.Z., El-Sheekh, M.M., Khalil, M.A., Elshouny, W.A.E. \& Badr, H.M. (2014) Seasonal and regional variation of physicochemical and bacteriological parameters of surface water in ElBahr El-Pherony, Menoufia, Egypt. World Journal of Fish and Marine Sciences, 6: 328-335.

Samanta P., Kumari P., Pal S., Mukherjee A.K., \& Ghosh, A.R. (2018). Histopathological and ultrastructural alterations in some organs of Oreochromis niloticus exposed to glyphosatebased herbicide, Excel Mera 71. Journal of Microscopy and Ultrastructure, 6: 35-43.

Selvanathan, J., Vincent, S. \& Nirmala, A. (2013). Histopathology changes in fresh water fish 
Clarias batirachius (Linn.) exposed to mercury and cadmium. International Journal of Life Science and Pharmaceutical Research, 3(2): 3438.

Sihtmae, M., Blinova, I., Kunnis-Beres, M., Kanarbik, L., Heinlaan, M. \& Kahru, A. (2013) Ecotoxicological effects of different glyphosate formulations. Applied Soil Ecology, 72: 215-224.

Sullivan, K.M. \& Somero, G.N. (1983). Size and diet related variations in enzyme activity and tissue compositions in the sablefish, Anoplopana fimbria. Biological Bulletin of Marine Biology Laboratory, 164: 315-326.
Thanomsit, C., Wattanakornsiri A. \& Nanthanawat, P. (2016). Effect of glyphosate on fish behavior and histological alteration of gills in Asian sea bass (Lates calcarifer) WHO (1994). Glyphosate. Environmental Health Criteria no.159, World Health Organization, Geneva.

Tomlin, C.D.S (2006). The Pesticide Manual: A World Compendium. Fourteen Edition. British Crop Protection Council: Hampshire, UK. Pp. 545-548. 